\title{
ILLEGAL ELECTION PRACTICES IN PHILADELPHIA
}

Each qualified citizen has the right to vote and to have his vote counted honestly; if elections are fraudulent, a citizen's vote is diluted or nullified to the extent to which votes are illegally cast. In the following material, an examination is made of the Pennsylvania election laws to determine who is responsible for honest elections in Philadelphia, why illegal election practices continue to exist and what remedies are possible. ${ }^{1}$

In determining whether there are in fact illegal election practices in Philadelphia, research was not limited to the relatively few convictions for violations of the Election Code but included interviews with district election officials, party watchers, election workers for a nonpartisan civic group, committeemen, ward leaders, office holders and defeated candidates. ${ }^{2}$

\section{Election Machinery}

For election purposes, Philadelphia is divided into fifty-two wards laving no uniformity as to area or population. ${ }^{3}$ Various combinations of these wards form city, state and congressional districts for those elective offices whose area of representation is based on population. Each ward is subdivided into districts which range in size from approximately 800 to 2,000 people; there are 1,535 districts in the city, each containing a polling place. $^{4}$

\section{The Polling Place}

The Election Code authorizes establishment of an election board in each district to supervise the casting of votes. ${ }^{5}$ The board is composed of an elected judge of elections, two elected inspectors of elections and an appointed clerk of elections. Each party nominates one judge of elections and one inspector of elections; the judge and the two inspectors receiving the highest number of votes are elected, the leading candidate for inspector being designated majority inspector while the other becomes minority inspector. ${ }^{8}$ Prior to the opening of the polls, the minority inspector ap-

1. The scope of the following materials on illegal election practices is limited to Philadelphia. But aside from minor variations arising from differences between the election laws of Pennsylvania and those of other states, the problem is present in most other cities. Pollack, They'll Steal Your Vote, 45 NAT'L MuNIC. REv. 322 (1956).

2. In evaluating the material gathered from these interviews, every effort was made to cross-check the responses with other individuals interviewed and, if possible, with a member of the opposition party.

3. The sixth ward has a population of approximately 1,000; the thirty-fifth ward, 195,000. Philadelphia City Planning Commission, Public Information Bulletin No. 6-c (Sept. 1955).

4. Committee of Seventy, Election Calendar (1957).

5. Pa. Stat. Ann. tit. 25, § 2671 (Purdon 1956).

6. Ibid. 
points the clerk of elections. ${ }^{7}$ Since it is practically certain that the minority inspector will appoint a person who is of the same party, an election board will consist of two members of each major party. Selection of the board in this manner theoretically insures that the election will be conducted in accordance with law since each party's representatives will presumably keep the other's under surveillance. Although the district judge of elections and the board are responsible for enforcement of the election laws, ${ }^{8}$ the Election Code provides for the additional safeguard of watchers. ${ }^{9}$ Watchers, and members of the board, all of whom must be residents of the district, ${ }^{10}$ are the only persons allowed in the polling place other than the voter. ${ }^{11}$

When an individual enters a polling place to vote, he is asked to sign a voter's certificate. This signature is compared with the signature on his registration card held by the clerk in the district register. If it appears to be genuine, he is allowed to enter the voting booth and vote. ${ }^{12}$ Before he does so, an election officer may instruct him on how to operate the machine by using authorized diagrams or a model voting machine. If the voter asks for instructions after he has entered the booth but before the curtain is closed, an election officer may comply with the request provided he does not ". . . request, suggest or seek to persuade or induce any such elector to vote any particular ticket or for any particular candidate. . . ."13 But the officer is not permitted inside the booth after the curtain is closed. ${ }^{14}$ No person in the polling place is allowed to solicit voters for a party or a candidate, and the posting of campaign literature is forbidden. ${ }^{15}$

Those voters who are illiterate or have a physical disability, and are so registered, may have another person enter the voting booth and assist them in voting. The judge of elections is required to keep a record of the electors who receive assistance, the names of the persons furnishing the assistance and the reasons for the assistance. ${ }^{16}$

7. Id. $\S 2674$.

8. Id. §§ 2677-79; Commonwealth v. Grear, 168 Pa. Super. 32, 76 A.2d 491 (1950).

9. Each candidate can appoint two watchers in a primary, and each political party can appoint three watchers in a general election. PA. STAT. ANN. tit. 25, \$ 2687 (a) (Purdon 1956). A candidate in a primary or a party in a general election can have only one watcher in the polling place at any given time. Id. $\S 2687(\mathrm{~b})$. If the electors of a division feel that additional protection is needed, a common pleas court, on petition of five resident electors of a division, will appoint two overseers to serve as additional deterrents to violations of the Election Code. Id. $\$ 2685$.

10. $I d . \S \S 2672,2687$ (b).

11. $I d . \$ \$ 3060(\mathrm{a}),(\mathrm{d})$.

12. $I d$. $\S 3050(\mathrm{a})$.

13. $I d . \S \S 3056(\mathrm{a})$, (b).

14. Ibid.

15. Id. $\$ 3060(\mathrm{c})$.

16. Id. $\S 3058$. Election officers who permit unlawful assistance are subject to a fine not exceeding $\$ 1,000$, or to undergo an imprisonment of not more than one year, or hoth, in the discretion of the court. Id. $\$ 3531$. A judge of elections who fails to keep and return a record of assisted voters is subject to a fine not exceeding one thousand dollars, or to undergo imprisonment of not less than two months nor more than two years, or both. Id. $\$ 3532$. The code also provides penalties of a fine of up to one thou- 
To enforce the sanctity of the polling place, the Election Code also prohibits bribery, ${ }^{17}$ intimidation, ${ }^{18}$ perjury ${ }^{19}$ and tampering with voting machines. ${ }^{20}$ Penalties for violations of the various provisions of the code range from one month ${ }^{21}$ to five years ${ }^{22}$ and/or a fine ranging from one hundred ${ }^{23}$ to one thousand dollars; ${ }^{24}$ disenfranchisement for four years is automatic upon conviction for violation of the Election Code ${ }^{25}$ and conviction of a candidate disqualifies him from holding any office in the future. ${ }^{26}$

\section{County Board of Elections}

Five elected county commissioners, constituting the County Board of Elections, are charged with overall responsibility for the conduct and supervision of elections. ${ }^{27}$ The board selects and equips polling places, supplies all election equipment, and stores, examines and prepares voting machines for elections. ${ }^{28}$ When it is necessary for a polling place to have more than one voting machine, the board appoints a machine inspector for each additional machine. ${ }^{29}$ It also issues watchers' certificates and is respoñsible for instructing district election officers in their duties. ${ }^{30}$

\section{The Registration Commission}

Registration of voters in Philadelphia is the responsibility of a bipartisan five-member commission appointed by the governor. ${ }^{31}$ No more than three members of the Commission can belong to the same political party, ${ }^{32}$ a further indication of the reliance placed by the Election Code on bipartisan representation to prevent dishonesty. The Commission supplies each polling place with a list of qualified voters and is responsible for

sand dollars, or imprisonment of up to one year, or both for an elector to allow someone to illegally assist him. The person who renders the illegal assistance is subject to the same penalty. Id. $\S 3530$. Guilty knowledge is not a necessary ingredient of the misdemeanor. Commonwealth v. Fine, 166 Pa. Super. 109, 70 A.2d 677 (1950).

17. Pa. Stat. Ann. tit. 25, § 3539 (Purdon 1956).

18. $I d . \S 3547$.

19. $I d . \S 3502$.

20. $I d . \S 3518$.

21. Id. $\S \S 3503,3505,3507,3508$.

22. Id. § 3523 .

23. $I d . \S 3509$.

24. See, e.g., id. \$\$3510, 3514-18.

25. $I d$. § 3552 .

26. $I d$. $\S 3551$.

27. $I d$. § 2641.

28. $I d . \$ \S 2642(\mathrm{~b}),(\mathrm{c})$.

29. Id. $\S 2642$ (d), 2674.

30. Id. $\$ \$ 2642(\mathrm{e}),(\mathrm{f})$.

31. Id. $\S 8623-3(\mathrm{a}),(\mathrm{b})$.

32. Id. $\S 623-3(\mathrm{~b})$. 
kèeping the lists accurate and up-to-date. ${ }^{33}$ To identify persons who have died or moved, it is authorized to use mail checks which request the elector to report any inaccuracies in his name or address, ${ }^{34}$ and to employ house-tohouse inspectors..$^{35}$ As a further safeguard against "phantom" voting in the names of people who are dead, incarcerated, or who have moved, any qualified elector may petition the Commission to strike off the names of improperly registered persons. ${ }^{36}$

Following each election, the Commission is directed to compare the signatures on voting certificates with those on the district register of each district and to report any indications of fraud to the district attorney. ${ }^{37}$

\section{Committee of Seventy}

The Committee of Seventy is a privately financed nonpartisan civic group that is active in most political matters concerning Philadelphia. On election day, the Committee employs college students to act as roving watchers to detect election frauds. These persons are without statutory authority to enter a polling place other than to vote at their own polling place. ${ }^{38}$ Complaints of illegal election practices that are received by the Committee are forwarded to these workers who attempt to check on them. Complaints that are substantiated and other illegal activities that are discovered by the Committee after election day are forwarded to the district attorney's office. ${ }^{39}$

\section{Violations OF THE CODE}

What happens in a polling place on election day is fully understandable only when viewed in the context of local politics during the remainder of the year. ${ }^{40}$ In each of the 1500 districts in Philadelphia each party elects two cotinmitteemen. These individuals, and the ward leader they elect, act as unofficial conduits through which residents of the district express their grievances to the city and seek information or services from the city or other agencies. On call at all times, the committeeman may be asked, for

33. Once a voter has registered, he does not have to do so again unless he changes his address or fails to vote for a two-year period. Id. $\S \S 623-21,623-40$.

34. Id. $\S 623-32$.

35. $I d . \S 623-33$.

36. Id. $\S 623-35$. If a petition is filed, a hearing is held and the Commission is to caricel the registration if the petition is justified. $1 d$. $\$ 623-36$.

37. Id. $\S 623-39$ (c).

38. Cf. id. $\S \S 2672,2685,2687$ (b), $2811(3)$.

39. See text and notes at notes $45,46,47$, and 50 infra. For a history of this organization, see Saturday Evening Post, Feb. 23, 1957, p. 43.

40. The information reported in text was gathered from interviews with people active in politics. See text following note 1 supra. Material written on this subject in the past includes ERvin, ThE Magistrates' Couris of Philadelphia 94-101, 105-08, 140 (1931) ; Kurtzman, Methods of Controlling Votes in Philadelphia (1935); MAIALE, THE ITALIAN VOTE IN PHILADELPHIA BeTWEEN 1928 AND 1946, at 102, 106, $107-09$ (1950) ; O'Neil, Philadelphia: Where Patience is a Vice, in OUR FAIR CITY 64 (Allen ed. 1947); Miller, The Negro in Pennsylvania Politics With Special Reiference to Philadelphia Since 1932, at 303-26 (1945); Salter, Boss Rule; PorTRAITS IN CITY Politics (1935). 
example, to "fix" or reduce the fine on a traffic ticket or summons, 41 "speak" to a magistrate before whom the voter will be appearing in a civil or criminal case, act as an intermediary between a member of the voter's family and a state senator in regard to a senatorial scholarship, or prepare and expedite a request to the city for some kind of permit. Having used his influence on behalf of his constituents, the committeeman or ward leader expects repayment. The day of payment occurs twice a year: primary election in the spring and general election in the fall.

\section{Illegal Assistance}

It has been estimated that approximately 100,000 people in Philadelphia lose their franchise each year through election frauds. ${ }^{42}$ Most of these votes are manipulated by district politicians who render illegal assistance by accompanying the voter into the polling booth and pulling the levers. In some of these cases the voter may have accepted a bribe. In the large majority of cases, however, the voter allows assistance for other reasons. $\mathrm{He}$ may feel indebted to the district politician for his past "services," 43 he may be uncertain as to the operation of the machine, or he may merely not want to affront his neighbor, the committeeman, by refusing his assistance. Aggravating the situation, typically, is the elector's ignorance of the candidates and issues involved, particularly in a primary, which renders him more susceptible to offers of aid.44

Not all sections of Philadelphia have the same socio-economic status; field investigation suggests that the lower the socio-economic level of the neighborhood, the more prevalent are illegal assistance and other violations of the Election Code. The river-to-river (east-west) area between Lehigh Avenue, twenty-seven city blocks north of Market Street (center city), and Snyder Avenue, twenty-one blocks south of Market Street, was found to contain the so-called "controlled" wards, ${ }^{45}$ where the vote is, to a large degree, determined by the illegal activities of local politicians. In some election districts in this area, it is unusual for an elector to vote unassisted in.a

41. The Evening Bulletin, March 15, 1957, p. 3, col. 6, has a story about the "new location" to which politicians were to bring traffic tickets to be "fixed." In recent months a new traffic court procedure has been inaugurated which is reputedly "fix proof." Until this system has been in operation for several months, politicians are reserving judgment on its effectiveness.

42. This was an estimate by a federal grand jury. Philadelphia Inquirer, Nov. 1, 1956, p. 7, col. 1.

43. See text at notes 40 and 41 supra.

44. Since a voter in a general election can pull either the Democratic or Republican lever and vote for all the party's candidates, it is not normally necessary to vote for or check on him unless the district politician has orders to "cut" a party candidate or feels the voter is untrustworthy or may make a mistake. It is at the primary election that illegal assistance is necessary if the committeeman is to deliver the vote that is expected of him. If the committeeman or ward leader delivers the expected vote, he looks forward to a reward of a government job or, if he is ambitious and has enough voter appeal outside the bounds of his district or ward, a nomination for an elective office.

45. The testimony of the Executive Secretary of the Committee of Seventv, a nonpartisan civic organization, before a federal grand jury is to the same effect. Philadelphia Inquirer, Oct. 11, 1956, p. 6, col. 3. 
primary. ${ }^{46}$ An independent candidate, running without party support, finds this an insurmountable obstacle because of the difficulty in securing enough loyal watchers who can comply with the residence requirement. Illegal assistance is not confined to this area, however, and in primaries it is said that there is no such thing as an "independent ward." 47

\section{Bribery and Other Violations}

Although outright bribery is not prevalent through most parts of the city, in lower socio-economic areas enough votes are bought, in important contests, to play a decisive role in carrying a district or ward. Even in these areas, it is often considered in bad taste to offer money to people with steady jobs. One committeeman summed up the practice in such cases as a matter of "buying the voter a shot of whiskey or a few cigars to show him that you are a right guy. That's not bribery." 48 Since this rarely occurs inside the polling place, detection is almost impossible. ${ }^{40}$ In return, the voter is often expected to permit another to do the actual voting for him after he signs the voter's certificate. This, of course, requires the connivance of the district election board. So also does the practice of removing voter certificates from the district register and taking them to the residences of voters in order to obtain their signatures so that votes may subsequently be cast on their behalf. In the "controlled" wards the nicety of obtaining the proper signature is sometimes ignored and people who no longer live in the district or who are dead or in prison on election day are "voted." 50

In sections of the city where outright bribery is deemed improper, "workers" are hired in important contests to help bring out the party voters. Since there is no legal maximum to the number of "workers" a party can hire, the employment of a large number of people from large families can accomplish the same results as bribery without violating the Election Code.

46. A former state representative and ward leader, still active in politics, boasted to us that if they voted for every elector in his division, and if the Committee of Seventy (evidently he was unconcerned about the district attorney) approached every voter the next day, the Committee would not be able to get a single person to testify that anything illegal occured.

47. See also Temple University News, April 30, 1956, p. 1, col. 2, reporting the results of two polls, covering the 1955 and 1956 city primaries, in which the students worked as volunteers for the Committee of Seventy. The students reported that a very low percentage of people were informed about the election and also the presence of illegal assistance.

48. Interview with committeeman, South Philadelphia ward.

49. Saturday Evening Post, Feb. 23, 1957, pp. 43, 96.

50. Interview with committeeman in forty-seventh ward; letters to district attorney by Committee of Seventy on Jan. 4, 1956 and Jan. 27, 1956 pertaining to the fourth, ninth, and thirty-sixth wards. In these letters, the names of voters who said that they did not vote, lived in another division, or who were in prison at the time of the election were listed. Also inclosed was a list of signatures which appeared to be forged; of these about forty-two signatures on the voter certificates in the first division of the ninth ward appeared to be signed by one person. See files, Committee of Seventy, Philadelphia, $\mathrm{Pa}$. for a report that in the first division of the ninth ward, out of one hundred and forty-five recorded voters, eighty-four were found to be fictitious names with doubt as to ten more; in addition, the district attorney's office could not locate the district board of elections. Up to August of 1956, no prosecutions for the above had been reported. Files, Committee of Seventy, Philadelphia, $\mathrm{Pa}$. 


\section{The Basic Weakness of the Election Code}

The theory that one party will prevent the other from violating the election laws ${ }^{51}$ breaks down completely in most primaries because each party is more concerned with having its endorsed candidates receive the nomination than with the results of the other party's primary. This concern, intensified by the comparative complexity of the primary, commonly results in each party concentrating on assisting its own voters, leaving the opposition party free to do the same. Independent candidates with active watchers at all polling places could presumably compensate for the inertia of the regular organizations. But in the majority of districts it is difficult for an independent to get watchers who will demand that their neighbors, the members of the board of elections and the committeemen, comply with the Election Code. Moreover, in districts where an independent has been unable to secure watchers, increased illegal activity may result in order to build up the vote against the independent. Not only is organization control of the party at stake, but there is need to set an example for those elected officials who might consider voting against the party while in office and subsequently running as independents should the party withhold its endorsement. 52

In general elections each party will serve as a watchdog on the other only if both parties are active and have strong organizations. The pendulum in Philadelphia has swung from Republican control to Democratic; in order to retain, or attain, patronage a number of former Republican committeemen have switched their registration and in February 1956, about half of these people were running for the position of committeeman on the Democratic ticket. ${ }^{53}$ Approximately fifty divisions have no elected Republican committeemen at all, ${ }^{54}$ and in some other districts the committeemen appear hardly competent to enforce the Election Code. Two of those interviewed, for example, were illiterates who themselves required assistance to vote.

In important elections, some district polling places are staffed with representatives of only one party because representatives of the other either do not appear or refrain from any activity. On this ground level of politics, the purchase price for a district "sell-out" is not great. 55

51. Even in theory bipartisan representation is not always insured since the code makes no provision for members of the division board of elections who change their party affiliation after they are elected. PA. STAT. ANN. tit. 25, § 2671-87 (Purdon 1956).

52. E.g., results of interviews with defeated candidates for the state legislature in South, West and North Philadelphia. See Philadelphia Bulletin, April 25, 1956, p. 1, col. 2, for an account of a nominee in a primary contest for the state legislature receiving two hundred and forty votes in one division and the other four candidates receiving none. In the other thirteen divisions in the ward, no other contestant received more than twenty votes.

53. Philadelphia Inquirer, Feb. 26, 1956, p. 13, col. 5, reported that more than one hundred Republican committeemen had switched their registration of whom about fortyeight are running for committee positions on the Democratic ticket. 1956.

54. Records of the County Board of Elections of committeemen elected in April,

55. To the effect that this situation is not peculiar to Philadelphia, see Election Frauds Can be Stopped, 45 NAT'L MuNIC. Rev. 321 (1956); Pollack, supra note 1. 
The Failure of the Enforcement Measures of the Code

\section{The Judge of Elections}

It is the function of the judge of elections to see that voting and the vote count are conducted properly. ${ }^{56}$ In some parts of the city, however, the job is looked upon as an easy way to make twenty-five dollars ${ }^{57}$ and not as a position of responsibility. Typically, this official's name is entered on the ballot on the recommendation of the district committeeman. Consequently, the judge is often a relative of the committeeman or someone from a family whose votes the committeeman is desirous of securing. If the committeeman is concerned with expediting his own job of delivering votes, it is unlikely that he will use competency, independence, or honesty as criteria in selecting his nominee for judge of elections. ${ }^{58}$

\section{County Board of Elections}

The County Board of Elections provides and maintains election equipment, certifies watchers and machine inspectors and gives instruction annually to the election officers of the various districts. ${ }^{59}$ A county commissioner who was interviewed was of the opinion that the Board's functions are limited to the aforementioned duties and that violations of the Election Code are the concern of the district attorney and the Committee of Seventy. He further observed that while violations are numerous, they are similar to violations of the traffic code; they can be reduced by publicity and a sustained enforcement drive, but never be wholly eliminated. Once the publicity and enforcement slackens, violations will be as numerous as before.

The Election Code provides that it is the duty of the Board to:

“. . . investigate election frauds, irregularities and violations of this act, and to report all suspicious circumstances to the district attorney." 60

“. . . inspect systematically and thoroughly the conduct of primaries and elections in the several election districts of the county to the end that primaries and elections may be honestly, efficiently and uniformly conducted." 81

The code could be interpreted to mean that the Board is to investigate elections only in retrospect and on the basis of its findings instruct and

56. See text and note at note 8 supra.

57. PA. Srat. Ann. tit. 25, § 2682 (a) (Purdon 1956).

58. Few of the judges of election that we spoke to had read the Election Code (they receive a copy of the code from the County Board of Elections) and misconceptions as to the provisions of the code are not uncommon. One judge of elections in South Philadelphia said that he permitted assistance whenever he thought that the voter was "nervous."

59. See notes 27-30 supra; PA. Strat. AnN. tit. 25, § 2642 (g) (Purdon 1938).

60. Pa. Stat. Ann. tit. 25, §2642(i) (Purdon 1938).

61. Id. $\S 2642(\mathrm{~g})$. 
issue rules to the district election boards so as to avoid future violations of the code. But the use of such phrases in the code as to "investigate election frauds," to "inspect systematically" and "to report all suspicious circumstances to the District Attorney," suggests a more dynamic role on election day itself. The Board, although unable to place a representative within a polling place because of the code enumeration of those allowed therein, ${ }^{62}$ might appoint roving inspectors to check on illegal practices by observation in the immediate vicinity of the polling places and by investigating complaints telephoned to the Board. ${ }^{63}$

\section{The Registration Commission}

One duty of the Registration Commission is to remove from the registration lists fictitious persons and those who have moved, died, or failed to vote in the last two years. ${ }^{64}$ It is important that the lists not be "padded" with such names because their presence facilitates fraudulent voting.

The Commission claims that its margin of error has been reduced to approximately one-half of one per cent, or 5,000 for $1,000,000$ voters. To accomplish this the Commission asserts that its investigators make a personal canvass of highly transient areas three times a year. ${ }^{65}$ This latter claim, however, was not substantiated by committeemen in these areas and in January 1956 it was discovered that of 145 votes cast in the first district of the ninth ward in the previous election, at least eighty-four had been cast in the names of fictitious people. The district attorney's office was also unable to locate the members of the district board of elections for the same reason. ${ }^{66}$

Another duty of the Registration Commission is to inspect the signatures on all voting certificates to insure that they correspond with the signatures in the registration binder. ${ }^{67}$ It is questionable, however, whether the inspection actually discloses forgeries because the employees of the Commission are not handwriting experts and their examination is probably cursory.

\section{The District Attorney}

On election day, the district attorney's office assigns fifteen to twenty assistant district attorneys to various sections of the city. When the office

62. Id. $\S \S 2672,2687(\mathrm{~b}), 2685,2811(3)$.

63. Absent a clearer statutory mandate or voluntary assumption of these duties, it may be difficult to compel the Board of Elections to undertake these duties. In Dorris v. Lloyd, $375 \mathrm{~Pa} .474,478,100$ A.2d 924, 927 (1953), it was held that a county chairman of a political party had no legal standing as an individual or in his representative capacity to maintain mandamus proceedings against county commissioners to inspect systematically the conduct of elections, because mandamus is not the proper remedy to compel a general course of official conduct or a long series of continuous acts to be performed under varying conditions.

64. See text at notes 32-35 supra.

65. Interview with Chairman of the Registration Commission, July, 1956.

66. See note 50 supra.

67. Pa. Stat. Ann. tit. 25, §623-39(c) (Purdon 1938). 
receives a complaint, the assistant district attorney assigned to that area is dispatched and is usually able to settle the dispute on the spot. According to the district attorney's office, there are only five or ten districts in which serious violations are attempted, and this system is a sufficient deterrent.

What apparently occurs when an assistant district attorney arrives at a polling place is that illegal practices are temporarily discontinued. Meanwhile the complaining witness has been persuaded to forget the incident. The effectiveness of the policy of attempting to settle election-day disputes on the spot may also be questioned. A Democratic watcher reported that in his district there was illegal assistance and bribery on a wholesale scale. The judge of elections, who was drunk, had cut a hole in the curtain and when he pushed an elderly lady out of the polling place, a complaint was made to the district attorney's office. The assistant district attorney who arrived took the judge of elections to one side, said something to him, and left after telling everyone present to "take it easy." 68

The effectiveness of the Election Code also depends on the extent to which discovered violators are prosecuted. Although there are many obstacles to prosecution of illegal election practices, because of intimidation and social pressures on witnesses, the district attorney's office has been fortunate enough to have a nonpartisan civic group obtain evidence of vote frauds for its office. ${ }^{69}$ A check of the bills of indictment returned by the grand jury from January 1,1955 to July 19, $1956^{\mathbf{7 0}}$ revealed that only two bills had been returned for election violations. Neither of these has been prosecuted. The professional politician at work on election day is not fearful of the district attorney's office.

\section{The United States Attorney}

In an election involving a federal office, every qualified elector has a federal right to vote ${ }^{71}$ and to have the vote honestly counted. ${ }^{72}$ Under two federal statutes, one providing penalties for deprivation of rights under color of law ${ }^{73}$ and the other punishing a conspiracy against the rights of citizens, ${ }^{74}$ the federal government has power to prosecute most vote frauds in these elections. Indictments under these statutes have been sustained for not counting votes honestly, ${ }^{75}$ stuffing a ballot box, ${ }^{76}$ and rendering illegal assistance to a voter. ${ }^{77}$

68. November, 1955 election.

69. See text at notes 37 to 39 supra.

70. Covering two general and two primary elections.

71. United States v. Saylor, 322 U.S, 385 (1944); United States v. Classic. 313 U.S. 299 (1941); Ex parte Yarbrough, 110 U.S. 651 (1884).

72. United States v. Mosley, $2: 8$ U.S. 383 (1915). The source of this right is the section of the Federal Constitution, which pertains to the election of members of Congress. See U.S. CoNsr. art. I, \$2.

73. 18 U.S.C. \& 242 (1952).

74. 18 U.S.C. $\$ 241$ (1952).

75. See note 73 supra.

76. United States v. Saylor, 322 U.S. 385 (1944).

77. Fields v. United States, 228 F.2d 544 (4th Cir. 1955). 
Congress has power, based on the fifteenth amendment, to legislate in regard to purely local elections in aid of qualified electors wrongly refused the franchise because of race, color, or previous condition of servitude. ${ }^{78}$ This power has been exercised by a statute giving a qualified elector who has been refused the right to vote because of his race a civil cause of action. ${ }^{79}$ In addition, the equal protection clause of the fourteenth amendment provides a source of jurisdiction over local elections in those cases involving state action. Congress, in enacting a statute prohibiting deprivation of rights under color of law, ${ }^{80}$ would seem to have exercised this jurisdiction in such a manner as to authorize prosecution of election officials for actions depriving a voter of his franchise. ${ }^{81}$ However, difficult evidentiary problems stand in the path of convictions. For example, federal courts would not be disposed to construe every violation of a state law by a state official as a denial of equal protection. ${ }^{82}$ It would be necessary to show that in violating the Election Code, the election officer intentionally or purposefully took this action with a specific intent to deprive the victim of a federally protected right. ${ }^{83}$ The difficulty of sustaining this burden is at once apparent because professional politicians at work on election day are concerned with the number of votes they can obtain and have no specific intent to deprive any individual of his right of the franchise. In addition, even if this burden can be met successfully, a watcher, who arguably may not be acting under "color of law," and a person unofficially in the polling place, who renders illegal assistance, would not be subject to federal jurisdiction.

Assuming that federal jurisdiction is available only in elections including federal offices, the potential of keeping elections honest is present. Members of the House of Representatives are elected every two years, and it is likely that zealous prosecutions for vote frauds would be a sufficient deterrent to professional politicians not only in Philadelphia, but nationally. Thus far, however, the federal government has generally left policing of elections up to the states as a matter of policy.

78. United States v. Reese, 92 U.S. 214 (1875).

79. REv. STAT. 2004 (1875), 42 U.S.C. \$ 1971 (1952). The federal attorney interviewed was of the opinion that this is the extent of federal jurisdiction in a local election.

80. 18 U.S.C. \& 242 (1952), protects those rights affirmatively granted by the United States Constitution and those rights secured from state interference. United States v. Classic, 313 U.S. 299, 325 (1941).

81. United States v. Classic, 313 U.S. 299, 325 (1941) (action of state election official violating the state election laws is action taken "under color of" state law). The statute punishing a conspiracy against the rights of citizens has been construed to protect from interference only those rights affirmatively granted by the United States Constitution. United States v. Williams, 341 U.S. 70 (1951). Since the right to vote in a purely local election is a state-created right, Snowden v. Hughes, 321 U.S. 1, 7 (1943), federal jurisdiction would not be obtainable under this statute.

82. Snowden v. Hughes, 321 U.S. 1, 8 (1943).

83. Screws v. United States, 325 U.S. 91, 104 (1945). 


\section{RECOMMENDATIONS}

The prevalence of election frauds in Philadelphia, especially illegal assistance, strongly indicates that the Election Code has not been effective. Yet relatively clean elections are possible, as was demonstrated in the presidential election of 1956 when the federal grand jury was sitting on election day and the Committee of Seventy had a large number of roving inspectors on the streets. ${ }^{84}$ Such preventive measures may not be feasible, however, at every future city election, particularly at primaries. Changes in the present code therefore appear necessary.

Post-election prosecution for violation of the Election Code is an inadequate deterrent to such conduct. To be effective, the code must establish a means of preventing fraud at the polling place. The present reliance on surveillance by each party of the other's conduct fails to satisfy this need, particularly at the primary. Nor does the judge of elections seem able to secure compliance with the code's requirements. However, this inability is more a product of the method by which he is selected than it is a weakness inherent in the concept of a judge of elections itself. A sincere attempt to enfore the code by a judge of elections familiar with its provisions would eliminate much of the present improper conduct, especially the rendering of illegal assistance. Herein, then, lies a possible avenue of reform.

Making the judge of elections an elective office insures that the local majority committeeman's nominee will fill the post. The individual chosen is open to two kinds of pressure: pressure from the committeeman to whom he owes his "appointment" and pressure resulting from any attempt to enforce the code against his neighbors. And, of course, if illegal activity is contemplated, it is unlikely that the committeeman will select a nominee likely to be able to resist such pressures.

An alternative is to amend the code to allow appointment of judges of election on a civil service basis, i.e., call for applicants, test them for general aptitude, and appoint those demonstrating the greatest ability to serve regularly at elections. Certain minimum standards, particularly freedom from a criminal record and possibly a high school education would be desirable. Those selected would then be given a course of instruction, more comprehensive than presently given, ${ }^{85}$ in the Election Code and would be assigned to districts other than that of their residence, the assignment to vary with each election. ${ }^{86}$ This divorcement from committeeman and neighborhood would appear to reduce the pressures presently on a judge of elections. In addition, selection by a more objective method would hopefully raise the level of competency of those holding the office.

84. Saturday Evening Post, Feb. 23, 1957, p. 43.

85. In interviewing judges of election, complaints were made that the one instruction period allotted to them was insufficient to teach them how to run a polling place.

86. It is thought that the purpose behind the residency requirement is that a resident board will recognize and stop voting by "floaters," i.e., persons who go from district to district and cast votes in the names of other persons. Since the remaining three members of the election board would continue to be residents of the district, this proposal would not thwart this purpose. 
Naturally, the proposal has certain disadvantages. Chief among them would be increased cost and administrative detail. ${ }^{87}$ However, it is believed that these could be minimized and that the gain in terms of more honest elections would offset them.

Two less drastic alternatives might yield certain of the advantages of this proposal at a reduced cost. The first of these would require amendment of the Election Code to permit the County Board of Elections to have inspectors present in the polling places. The Board should then be placed under civil service (probably a desirable course in any event) and given authority to hire inspectors in the same manner as suggested for judges of election. These inspectors, under the power of the Board to inspect the conduct of primaries and elections, could be assigned as watchers where needed or used as roving inspectors. A second alternative, which could also be used to supplement the prior suggestions, would amend the residency requirement for watchers so as to permit representation of independent candidates and civic groups such as the Committee of Seventy in the polling places. ${ }^{88}$ Such representatives might be expected to scrutinize more closely the activities of the regular party organizations.

The first of these alternatives does not promise complete coverage of polling places, nor does it place reliance on the individual theoretically in charge of the polling place. The chief advantage of this suggestion would be the lower cost as compared to the expense of advertising, testing, and selecting of judges of election necessary for complete coverage of the city's polling places. The second alternative, involving no additional cost to the city, would have the same disadvantage as to scope of coverage since the attainment of its desired purpose would depend on the self interest of independent candidates and the judgment of independent civic organizations as to which polling places need additional supervision.

87. Among these would be advertising for people to fill the positions, preparing and administering a test and training those persons who are selected. Probably the cost of advertising would not be great since it is likely that the local newspapers and civic groups would be willing to actively assist the county board.

88. For statutes not requiring that either the division election officials or watchers be residents of the division in which they serve, see, e.g., IIL. ANN. STAT. c. 46, \$ 18-6 (Smith-Hurd 1956); Mich. Stat. ANN. \$ 6.1677 (1956); N.Y. Electron LAw \$ 39(3). Because of the dearth of investigative material on the subject, it is not known whether those states not having a residency requirement have a lower incidence of violations of their election codes. However, since statutory commands alone will not insure honest elections, the machinery to prevent election code violations should be available to any interested party, e.g., an independent candidate or a civic group, who is likely to use it. 